mércio exterior, dos bancos muito atuantes no euromercado, mas dos bancos comerciais nacionais, muita imaginação e criatividade, no sentido de tornar mais ágeis esses mecanismos, facilitar os contratos e os sistemas de garantias, porque verificamos, cada vez mais, que tais complicações provocam, aos bancos comerciais chamados a financiar parte substancial desse esforço, problemas de toda natureza no mundo conturbado em que vivemos.

Os bancos comerciais, por exemplo, que complementam os esforços do governo no financiamen- to do comércio exterior, utilizam fortemente suas linhas de crédito junto a outros bancos comerciais; utilizam de eurodivisas, mais conhecidas como eurodólares, e cada vez mais eles se endividam a curto prazo para atender a requisitos de financiamento a longo prazo, porque implicam riscos sempre maiores e, portanto, esforço adicional de imaginação de atividade da parte daqueles assessores jurídicos, no sentido de melhorar o ambiente e tornar mais fáceis todos os instrumentos utilizados, evitando, naquilo que for possível, os entraves da burocracia.

\title{
Os bancos comerciais nas operações de financiamento de comércio exterior
}

Paulo de Souza Campos Filho, da Diretoria do Banco Real S/A.

\section{Paulo de Souza Campos Filho}

Como elemento voltado estritamente para a prática dos negócios e não tanto para a teoria dos financiamentos ou para os grandes projetos de financiamento, feitos pelo Banco Mundial, sentimos que, paulatinamente, os bancos brasileiros têm encontrado condições, através da abertura de agências, não apenas nos grandes mercados financeiros, mas em alguns dos mercados consumidores de produtos de exportação brasileira; os bancos têm encontrado condições de, com recursos locais, facilitar c financiamento das exportações brasileiras. Essa é a participação do Banco Real hoje, com uma rede de agências em praticamente toda a América Latina (só não temos agências onde a legislação não permite). E temos, com isso, na medida do possível, procurado ajudar o desenvolvimento das exportações brasileiras.

Na parte que me compete, mais como advogado, eu gostaria de citar uma extrema dificuldade: - Brasil, pelo fato de ser um país carente de recurSos, carente de divisas - carente de recursos financeiros, não de recursos materiais - , tem uma politica cambial não muito flexível, bastante fixa, e, em algumas ocasiões, tivemos oportunidade de ver que essa política dificulta a colocação, não da exportação do grande serviço ou do grande produto brasileiro, mas de complemento das exportações brasileiras, vamos dizer, por exemplo, tivemos no Uruguai uma construtora brasileira que ganhou a concorrência para a construção de uma usina hidrelétrica, a Usina de Palmare, à medida em que os serviços conexos começaram a ser colocados em concorrência
- como por exemplo é o caso específico que eu gostaria de citar: o serviço de colocação das torres de transmissão da energia - pequenas empresas brasileiras tiveram condições de pretender se aventurar a uma atividade de exportação; empresas brasileiras que são pequenas aqui, ou que são médias aqui, mas que são pequenas para um porte internacional de exportadora, que tiveram dificuldade, que foram inclusive ao banco e não conseguiram apresentar, por exemplo, cartas de garantia de bancos internacionais emitidas fora do Brasil. Para a apresentação de propostas na concorrência, apresentaram uma espécie de big bond, porque os bancos internacionais não financiariam uma empresa muito pequena para o porte internacional e não conhecida. Os bancos brasileiros têm dificuldade de fornecer determinadas garantias financeiras a essas empresas - e, no nosso caso, temos um banco no Uruguai que poderia fornecer a carta de garantia pela impossibilidade ou pela falta de um instrumento ágil de remessa dessas divisas para efetuar o pagamento do governo do Uruguai, se fosse o caso de uma penalidade ou alguma coisa assim, em virtude do tempo que demanda uma aprovação para uma garantia que envolva a possibilidade de remessa de divisas posteriores para o exterior.

Então, hoje, examinando a regulamentação vigente, vemos que o grande exportador de serviços brasileiros, como as grandes construtoras, têm encontrado apoio nesta regulamentação e um apoio, logicamente, dos bancos; mas o pequeno exportador que serviria para cobrir certas necessidades que 
não são as principais da obra, estes têm dificuldade muito grande por falta de tradição no mercado e pela dificuldade que os bancos têm hoje de atender a exportadores por falta de instrumental jurídico ou de câmbio, na necessidade eventual de remessas urgentes de divisas. Quando muito poderiam socorrerse de divisas fornecidas pelas unidades externas dos bancos, mas sem uma garantia para o banco de que essas divisas pudessem depois transitar rapidamen- te do Brasil para o exterior, para cobrir as eventuais despesas ou até eventuais prejuízos desses pequenos exportadores.

Essa é a matéria que merece hoje atenção maior, para que nós possamos ampliar a exportação, não em volumes enormes com poucas operações, mas em volume apreciável de operações de menor valor.

\section{Diferenças entre o sistema brasileiro e europeu de seguro de crédito à exportação}

Hans Joachim Pretzell, diretor da Empresa Kluckner Group Company, Londres.
Os europeus estão realmente melhor protegidos. O Clube de Berna (Bern Union ), por exemplo, que congrega quese todos os países industrializados, regulamentou as diferentes modalidades de crédito. Alguns sistemas são sofisticados, como o francês e o inglês. No sistema inglês, um dos grandes riscos, por exemplo nas licitações internacionais, é a manutenção de um preço estável: o governo inglês provê, através do Departamento de Garantia de Crédito à Exportação - ECGD, a possibilidade de um seguro de inflação durante o período de licitação e o de construção da fábrica, contemplando projetos que, às vezes, se prolongam por doze meses.

Outra facilidade inglesa, não-existente no Brasil, é a escolha de uma moeda mais barata do que a libra esterlina (sempre muito forte, em virtude das taxas de juro), facultada ao exportador de bens de capital em meio a competidores, digamos, do Japão, que oferecem o produto em Yen. Outra facilidade, ainda existente sobretudo na França e na Inglaterra, são os chamados buyer's credits, os quais habilitam o exportador a calcular o preço contratual à base de um preço à vista cash-price, o que implica em assumir o governo inteiramente os riscos políticos e comerciais pelo não-reembolso do comprador estrangeiro, vantagem esta extraordinária sobre países como o Japão ou a Alemanha Ocidental, que adotam o supplier's credit, pelo qual o exportador se obriga a calcular uma participação entre 15 e $25 \%$ conforme a credibilidade do comprador. Nas facilidades vigentes no Reino Unido: oferecimento de um conjunto de apólices (big bond), que podem também ser seguradas, minimizando o risco do exportador; seguro contra insolvência ou dificuldades financeiras de um sócio estrangeiro durante a execução de um contrato.

Tais são as grandes vantagens existentes na Europa Ocidental, às quais ainda se poderiam acrescentar os esquemas internacionais de financiamento à exportação, que se tornam cada vez mais sofisticados, a fim de se superarem uns aos outros na conquista dos escassos projetos, razão por que, a despeito de todos os acordos e protocolos, cada país concentra esforços no sentido de uma ou duas regras em casos específicos.

A questão final prende-se ao estabelecimento da garantia de credibilidade de um país receptor, o que é um procedimento secreto entre as nações da Bern Union, as quais se reúnem uma vez por mês para troca de experiências. No Reino Unido, por exemplo, existem quatro diferentes categorias de garantias, sendo o prêmio a ser pago pelo exportador à ECDG, na dependência da credibilidade do país, como já visto, conservado em segredo, de modo que no país do cliente não se possa saber a posição do crédito junto às autoridades inglesas, francesas ou alemãs. 